\title{
The effect of $\mathrm{BaCO}_{3}$ addition on the sintering behavior of lignite coal fly ash
}

\author{
B. Ersoy ${ }^{a, *}$, T. Kavas ${ }^{a}$, A. Evcin ${ }^{a}$, S. Başpınar ${ }^{a}$, A. Sarışık ${ }^{a}$, G. Önce ${ }^{b}$ \\ ${ }^{a}$ Afyon Kocatepe University, Engineering Faculty, 03200 Afyonkarahisar, Turkey \\ ${ }^{\mathrm{b}}$ Dumlupinar University, Engineering Faculty, 43100 Kütahya, Turkey
}

\section{A R T I C L E I N F O}

\section{Article history:}

Received 10 September 2007

Received in revised form 13 March 2008

Accepted 13 March 2008

Available online 11 April 2008

\section{Keywords:}

Coal fly ash

$\mathrm{BaCO}_{3}$

Sintering

XRD

Electron microscopy

\begin{abstract}
A B S T R A C T
The effect of $\mathrm{BaCO}_{3}$ (witherite) addition on the sintering behavior of lignite coal fly ash taken from the Seyitömer power plant of Kütahya/Turkey was examined at temperatures of 1100,1150 and $1200{ }^{\circ} \mathrm{C}$ in air atmosphere. Bloating of the fly ash samples sintered at $1150^{\circ} \mathrm{C}$ was prevented, that is, the decomposition temperature of $\mathrm{CaSO}_{4}$ in the fly ash is shifted to a higher temperature, and their physicomechanical properties (porosity, water absorption, bulk density and bending strength) were improved with $\mathrm{BaCO}_{3}$ addition. Positive effects of $\mathrm{BaCO}_{3}$, however, were not seen on the fly ash samples sintered at $1100{ }^{\circ} \mathrm{C}$. All the fly ash samples sintered at $1200^{\circ} \mathrm{C}$ were bloated due to the gas evolving and also they melted. During the thermal treatment at $1150{ }^{\circ} \mathrm{C}$ a phase transformation from $\mathrm{CaSO}_{4}$ (anhydrite) to $\mathrm{BaSO}_{4}$ (Barite) occurred in the fly ash with $\mathrm{BaCO}_{3}$ addition as seen from the X-ray diffraction (XRD) patterns and the bar shaped fly ash samples with $\mathrm{BaCO}_{3}$ saved their structural integrity up to $1150{ }^{\circ} \mathrm{C}$.
\end{abstract}

(c) 2008 Elsevier Ltd. All rights reserved.

\section{Introduction}

Fly ash is the finely divided mineral residue resulting from the combustion of pulverized coal in thermal power plants. Every year a large quantity of fly ash is produced in the world. For instance, only in Turkey more than 13 million tons of fly ash is produced annually and this amount is expected to reach 50 million tons per year by 2020 [1,2]. But, only a small amount of this waste fly ash in Turkey approximately $1 \%$ is reused in construction industry particularly cement industry [3], the rest is disposed into ash dumps or landfill which is an inconvenient solution both from the environmental and economical point of view. Reusing ratio of fly ash generated in all the world is about $10-20 \%$ of the total amount [4]. Numerous studies have been performed in order to find out application areas for the waste fly ash. It has been pointed out that fly ash can be used as additive in cement industry [5-7] and building industry for brick making [1,8-10], for glass [11$15]$, light weight materials $[16,17]$, ceramic tableware and artware [18], mullite [19], composite materials [20], and sintered material [21] production.

The fly ashes collected by electrostatic precipitators of power plants are usually finely sized (less than $100 \mu \mathrm{m}$ ) and spherical shaped particles, and consists of $\mathrm{SiO}_{2}, \mathrm{Al}_{2} \mathrm{O}_{3}, \mathrm{Fe}_{2} \mathrm{O}_{3}$ as major components and alkali and earth alkali metal oxides (i.e. $\mathrm{Na}_{2} \mathrm{O}, \mathrm{K}_{2} \mathrm{O}$, $\mathrm{CaO}, \mathrm{MgO}$ ) [7]. For this reason, sintering seems to be the most suitable way to convert the fly ash to useful fired products. The sintering behavior of powder materials such as fly ash is depen-

\footnotetext{
* Corresponding author. Tel.: +90 272 2281423; fax: +90 2722281422

E-mail address: bersoy@aku.edu.tr (B. Ersoy).
}

dent on its chemical and mineralogical composition, physical properties, i.e. particle size, shape, and thermal treatment conditions $[9,21,22]$. Actually chemical and mineralogical components and physical properties of fly ashes vary depending on coal type (i.e. anthracite, bituminous coal, lignite and sub-bituminous coals) and combustion conditions of pulverized coal (i.e. dry combustion $\left(1100-1400^{\circ} \mathrm{C}\right)$, high temperature combustion $\left(1500-1700^{\circ} \mathrm{C}\right)$ and fluidized bed combustion $\left(<900^{\circ} \mathrm{C}\right)$ ) and fly ash collection operations (i.e. cyclone, electrostatic precipitation, bag filters) $[7,21,23]$. As a result, it is expected that the sintering behavior of each fly ash may be different from each other. Therefore, sintering behavior of each type fly ash needs to be investigated. On the other hand, sintering behavior becomes more important according to new approach of the production of bricks from $100 \%$ fly ash $[9,10]$. This approach is seemed to be a good way for consumption of the enormous fly ash waste and environmental protection.

Studies on sintering behavior of fly ash without chemical additive reported that the fly ash was bloated at high temperature $\left(1200^{\circ} \mathrm{C}\right)$ in which Seyitömer fly ash sample was used similar to that in this study [8], but the study does not cover the temperatures between 1100 and $1200{ }^{\circ} \mathrm{C}$. Bulk density and bending strength of the fly ash samples sintered between at 900 and $1050^{\circ} \mathrm{C}$ was enhanced with decrease of particle size of fly ash [9]. The fly ash based glass-ceramic obtained at $924{ }^{\circ} \mathrm{C}$ consists of only the diopside phase and indicated that fly ash can be used to produce glass-ceramic [11]. The sintering process between 1130 and $1190{ }^{\circ} \mathrm{C}$ reduced the amount of glass, quartz, gehlenite and anhydrite phases which are present in milled fly ash with average particle size of $5.6 \mu \mathrm{m}$, but increased formation of 
anorthite, mullite, hematite and cristobalite, in addition, the best density was obtained at $1170{ }^{\circ} \mathrm{C}$ while bloating was occurred at $1190^{\circ} \mathrm{C}$ due to the decomposition of alkaline metal salts [21]. Considering the shrinkage curve of the fly ash sintered between 600 and $1200^{\circ} \mathrm{C}$, two densification stages were obtained, the first operates in the $800-1070^{\circ} \mathrm{C}$ range and the second one at temperatures higher than $1180^{\circ} \mathrm{C}$, while between the two stages the densification remains constant, densification process observed above $1180^{\circ} \mathrm{C}$ is controlled by liquid phase [24]. Even though the tridymite is more stable phase than crystobalite at temperatures $\geqslant 900{ }^{\circ} \mathrm{C}$, crystobalite phase was seen in the sintered fly ash at between 1000 and $1200{ }^{\circ} \mathrm{C}$ [25]. A detailed study has been performed by Erol et al. [26] on characterization of sintered (at $1170^{\circ} \mathrm{C}$, for $2 \mathrm{~h}$ ) different Turkish fly ashes including Seyitömer fly ash showed that under the working conditions, mullite and anorthite phases were occurred in the sintered samples of SFA which have high density $\left(2.43 \mathrm{~g} / \mathrm{cm}^{3}\right)$ low water absorption (3 wt\%) and porosity (2.1\%). The bloating and swelling problem occurring during sintering of the fly ashes including anhydrite at relatively high temperatures $1190-1200{ }^{\circ} \mathrm{C}$ is mentioned in two studies $[8,21]$.

In thermal treatment researches regarding fly ash with chemical additive, Sheng et al. [12] studied on the effect of $\mathrm{Na}_{2} \mathrm{O}$ addition ( $\sim 10 \mathrm{wt} \%$ ) on vitrification of fly ash at $1200^{\circ} \mathrm{C}$ and obtained glass products of good chemical durability in order to immobilize heavy metals. Satapathy pointed out that bulk density of the sintered fly ash at $1255^{\circ} \mathrm{C}$ was increased whereas its linear shrinkage remained constant with the additions of zirconia $\left(\mathrm{ZrO}_{2}\right)$ up to $25 \mathrm{wt} \%$ in fly ash [27].

$\mathrm{BaCO}_{3}$ has many major commercial applications in glass, ceramic and building industries $[28,29]$. In the glass industry, barium is added to glass as barium carbonate or barium oxide to improve the refractive index of optical glass; also to promote sintering and lower the viscosity of melted glass. It is used as a fluxing ingredient in ceramic industry enamels, glazes and ceramic bodies. It is reported that the addition of $\mathrm{BaCO}_{3}$ significantly reduced the time and temperature of formation of $\mathrm{C}_{3} \mathrm{~S}$ (tricalcium silicate) phase during firing clinker in cement owing to the replacement of $\mathrm{Ba}^{2+}$ with $\mathrm{Ca}^{2+}$ in the phase at $1450{ }^{\circ} \mathrm{C}[30] . \mathrm{BaCO}_{3}$ is used in brick industry to prevent the efflorescence $[31,32]$ forming undesirable white deposit on fired building materials resulting from water-soluble salts such as $\mathrm{CaSO}_{4}$ and $\mathrm{Na}_{2} \mathrm{SO}_{4}$, through converting reaction from soluble salt to insoluble salt (i.e. $\mathrm{BaSO}_{4}$ ). Moreover, the existence of alkaline and alkaline earth metal salts such as $\mathrm{CaSO}_{4}$ in ceramic raw materials might damage fired ceramic product (i.e. brick)'s structure due to its thermal decomposition during firing $[8,21,32]$ and additionally the temperature of decomposition of $\mathrm{CaSO}_{4}$ is lowered in the presence of $\mathrm{SiO}_{2}$ [33]. For instance, while the decomposition temperature of nearly pure $\mathrm{CaSO}_{4}$ is about $1240{ }^{\circ} \mathrm{C}$, it reduces to about $1120^{\circ} \mathrm{C}$ in the presence $25 \mathrm{wt} \%$ silica in air at a heating rate of $10^{\circ} \mathrm{C} / \mathrm{min}$ [33]. The fly ash used in this study includes $\mathrm{CaSO}_{4}$ and $\mathrm{SiO}_{2}$ in addition to other minerals. Accordingly, it is thought that the decomposition on $\mathrm{CaSO}_{4}$ may be shifted to higher temperature by forming of $\mathrm{BaSO}_{4}$ phase by means of $\mathrm{BaCO}_{3}$ addition. However, it is uncertain how the other components such as silica, alumina, and iron oxide existing together with $\mathrm{BaSO}_{4}$ change the decomposition temperature while the decomposition temp of $\mathrm{BaSO}_{4}$ as alone is about $1170{ }^{\circ} \mathrm{C}$ in air at the speed of $10^{\circ} \mathrm{C} / \mathrm{min}$ according to our DTA analysis (data not given here).

According to the knowledge of the authors, the effect of $\mathrm{BaCO}_{3}$ addition on the sintering behavior of coal fly ash has not been studied. Therefore, the main objective of this study is to see how $\mathrm{BaCO}_{3}$ affects the sintering behavior of the Seyitömer fly ash including $\mathrm{CaSO}_{4}$ (anhydrate) at relatively high temperatures of 1100,1150 and $1200{ }^{\circ} \mathrm{C}$.

\section{Experimental procedures}

The fly ash used in the experiments was taken from the electrostatic precipitator bag of Seyitömer Power Station in Kütahya-Turkey, burning the pulverized lignite coal. Its chemical analysis by EDXRF (Energy-dispersive X-ray fluorescence) spectrometry technique (Spectro ${ }^{\mathrm{m}} \mathrm{X}$-LAB 2000), carbon content using combustion and IR absorption technique (Multilab ${ }^{\mathrm{m}}$ - CS Determinator), particle size using laser diffraction method (Malvern ${ }^{\mathrm{m}}$ Mastersizer 2000), specific surface area using $\mathrm{N}_{2}$ gas adsorption method by BET (Micromeriticies ${ }^{\mathrm{m}}$ Gemini 2360) and specific gravity using helium-picnometer (Micromeriticies ${ }^{\mathrm{TM}}$ Autopycnometer 1320) were carried out. These analyses are given in Table 1 . Besides, in order to check the obtained results related to the negative influence of $\mathrm{BaCO}_{3}$ on the sintered samples with $\mathrm{BaCO}_{3}$ at $1100{ }^{\circ} \mathrm{C}$, pore structure analysis (average pore diameter and total pore area) on the two different samples without and with $10 \mathrm{wt} \% \mathrm{BaCO}_{3}$ were performed by mercury porosimeter technique (Micromeriticies ${ }^{\text {m }}$ Autopore II 9220). Table 1 indicates that the main chemical components of the Seyitömer fly ash are $\mathrm{SiO}_{2}$ and $\mathrm{Al}_{2} \mathrm{O}_{3}$, and the other important amounts of oxides are $\mathrm{Fe}_{2} \mathrm{O}_{3}, \mathrm{CaO}, \mathrm{MgO}$ and $\mathrm{SO}_{3}$. Loss on ignition (LOI) of the fly ash mainly results from the unburned carbon content. According to ASTM C618, which considers basically the chemical components of fly ash, the Seyitömer fly ash is a class $\mathrm{F}$ $\left(\mathrm{SiO}_{2}+\mathrm{Al}_{2} \mathrm{O}_{3}+\mathrm{Fe}_{2} \mathrm{O}_{3} \geqslant 70 \mathrm{wt} \%\right)$ fly ash [34]. The both chemical and particle size analysis results are in generally agree with Yllmaz et al. [8], whereas they do not agree with these analysis of Erol et al. [26]. This indicates that the differences between the fly ash samples even in the same type of fly ash may be possible. $\mathrm{BaCO}_{3}$ in $99 \%$ purity was from Lancaster firm (England) and the other properties of the $\mathrm{BaCO}_{3}$ used are: specific gravity $4.3 \mathrm{~g} / \mathrm{cm}^{3}$, solubility $0.02 \mathrm{~g} / \mathrm{l}\left(\mathrm{H}_{2} \mathrm{O}, 20^{\circ} \mathrm{C}\right)$, melting point $811^{\circ} \mathrm{C}$, boiling point $1300{ }^{\circ} \mathrm{C}$ and appearance white powder.

$\mathrm{BaCO}_{3}(0,5$ and $10 \mathrm{wt} \%)$ was added into the fly ash and the mixture was wet milled in a ball mill using alumina balls for $3 \mathrm{~h}$. Subsequently, $10 \mathrm{~mL}$ of sample was taken from each suspension and their average particle size distributions were between 8.1 and $8.4 \mu \mathrm{m}$ (Mastersizer 2000). The milled suspensions were dried in an oven at $105^{\circ} \mathrm{C}$ for $5 \mathrm{~h}$ and then passed from a blender for 10 min to comminute. Water was added into the powdered samples at the ratio of $15 \mathrm{wt} \%$ for shaping, and then mixed. The moistened samples were passed from a sieve of $355 \mu \mathrm{m}$ to obtain granulated particles. The bar shaped samples (or representative bricks) in dimensions of $10 \times 10 \times 50 \mathrm{~mm}$ were uniaxially pressed under the load of $98 \mathrm{MPa}$ and dried at room temperature for two

\section{Table 1}

Chemical composition and some physical properties of the Seyitömer fly ash (asreceived)

\begin{tabular}{lc}
\hline Component & wt $\%$ \\
\hline $\mathrm{SiO}_{2}$ & 53.1 \\
$\mathrm{Al}_{2} \mathrm{O}_{3}$ & 19.2 \\
$\mathrm{Fe}_{2} \mathrm{O}_{3}$ & 10.4 \\
$\mathrm{CaO}$ & 4.6 \\
$\mathrm{~K}_{2} \mathrm{O}$ & 1.8 \\
$\mathrm{MgO}$ & 3.9 \\
$\mathrm{Na}_{2} \mathrm{O}$ & 0.8 \\
$\mathrm{SO}_{3}$ & 3.0 \\
$\mathrm{LOI}$ & 3.2 \\
$\mathrm{Total}_{\mathrm{Specific}}$ gravity $\left(\mathrm{g} / \mathrm{cm}^{3}\right)$ & 100 \\
$\mathrm{Carbon}($ wt\%) & 2.08 \\
Specific surface area $\left(\mathrm{m}^{2} / \mathrm{g}\right)$ & 1.47 \\
Particle size $(\mu \mathrm{m})$ & 0.182 \\
D90 & \\
D50 (average particle size) & 92 \\
D10 & 64 \\
\hline
\end{tabular}


days followed by determining dimensions and weight of the samples. The samples were sintered at 1100,1150 and $1200{ }^{\circ} \mathrm{C}$ in air atmosphere with the heating rate of $240^{\circ} \mathrm{C} / \mathrm{h}$ for $1 \mathrm{~h}$ in an electrical furnace. The cooling rate was $240^{\circ} \mathrm{C} / \mathrm{h}$. After firing linear shrinkage (\%) of the samples were determined. Then, water absorption tests according to Archimedes principle were applied on the sintered samples and thus water absorption (wt\%), bulk density $\left(\mathrm{g} / \mathrm{cm}^{3}\right)$ and apparent porosity (vol\%) of the samples were calculated. Three-point bending strength was measured with $35 \mathrm{~mm}$ span length at the cross-head speed of $1 \mathrm{~mm} / \mathrm{min}$ (Instron $^{\mathrm{TM}} 1150$ ). The each data used in the curves in Fig. 5 is average of the test results taken from the six samples. Physical and mechanical tests were not able to apply on the samples sintered at $1200{ }^{\circ} \mathrm{C}$ due to their unsuitable forms as seen from their photographs in Fig. 1. In order to clarify the effect of $\mathrm{BaCO}_{3}$ addition on the sintering behavior of the fly ash, X-ray diffraction and electron microscopy techniques were used. Phase analysis of both the as-received fly ash and the sintered fly ash without and with $\mathrm{BaCO}_{3}$ additive were performed by XRD (Rigaku ${ }^{\mathrm{m}}$ miniflex) using $\mathrm{Cu} \mathrm{K}_{\alpha}$ radiation (at $2 \theta$ scanning speed of $2 \% \mathrm{~min}$ ). The secondary electron images of fracture surfaces of the sintered samples were obtained from a scanning electron microscope (SEM, Leo ${ }^{\mathrm{T}}-1430 \mathrm{VP}$ ) equipped with an energy dispersive (EDS) spectrometry. Before SEM analysis, the fractured surfaces of the samples were coated with gold.

\section{Results and discussion}

\subsection{Photographs}

The photographs of the fly ash samples without and with $\mathrm{BaCO}_{3}$ additive (5 and $10 \mathrm{wt} \%$ ) sintered at 1100,1150 and $1200{ }^{\circ} \mathrm{C}$ are seen in Fig. 1. The photographs shows that considering their appearance; (i) All samples (without additive and with $\mathrm{BaCO}_{3}$ additive) sintered at $1200{ }^{\circ} \mathrm{C}$ were bloated totally due to the gas evolving and lost their structure entireness. A melting for the all samples is clearly seen at this temperature. That is, three separate bar

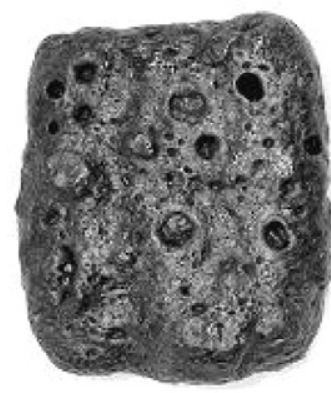

$1200{ }^{\circ} \mathrm{C}$, non-additive

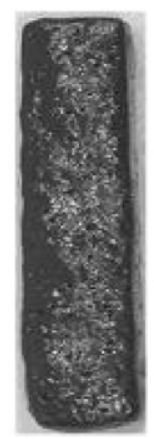

$1150{ }^{\circ} \mathrm{C}$, non-additive

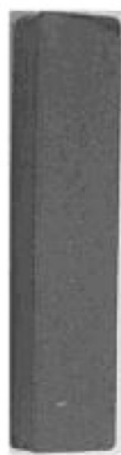

$1100{ }^{\circ} \mathrm{C}$, non-additive

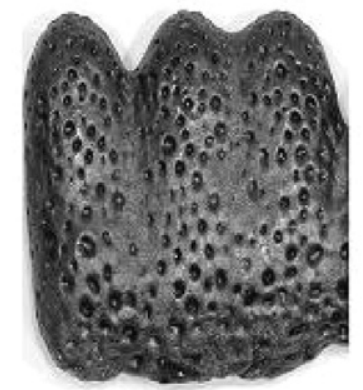

$1200{ }^{\circ} \mathrm{C}, 5 \mathrm{wt} \% \mathrm{BaCO}_{3}$

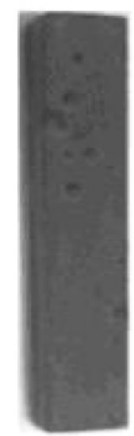

$1150{ }^{\circ} \mathrm{C}, 5 \mathrm{wt} \% \mathrm{BaCO}_{3}$

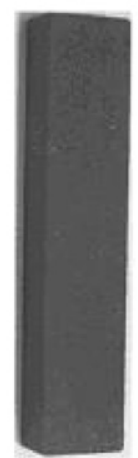

$1100{ }^{\circ} \mathrm{C}, 5 \mathrm{wt} \% \mathrm{BaCO}_{3}$

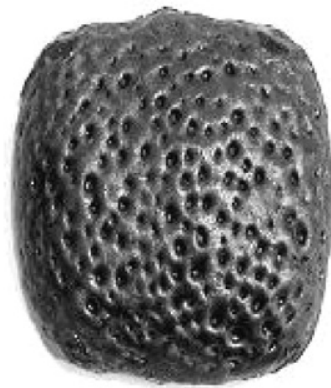

$1200{ }^{\circ} \mathrm{C}, 10 \mathrm{wt} \% \mathrm{BaCO}_{3}$

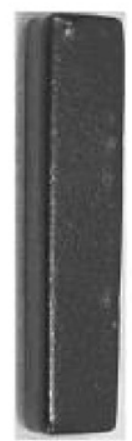

$1150{ }^{\circ} \mathrm{C}, 10 \mathrm{wt} \% \mathrm{BaCO}_{3}$

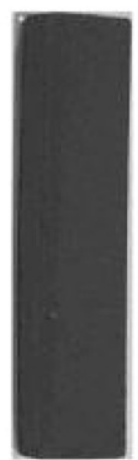

$1100{ }^{\circ} \mathrm{C}, 10 \mathrm{wt} \% \mathrm{BaCO}_{3}$

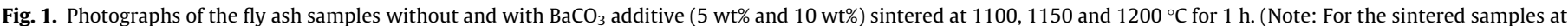

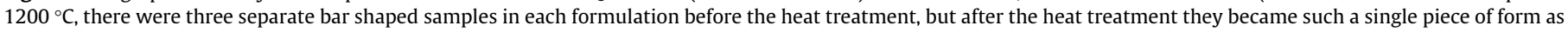
seen up.) 
shaped samples exist before firing but they turned a single piece after firing possibly as a result of melting as seen from the Fig. 1. Moreover, with increasing the amount of $\mathrm{BaCO}_{3}$ additive, melting was promoted due to its fluxing effect. While the vitrified samples without $\mathrm{BaCO}_{3}$ had heterogeneous large porous the $\mathrm{BaCO}_{3}$ added samples resulted in samples with a small sized and homogenous porous caused by fluxing effect of $\mathrm{BaCO}_{3}$. On the other hand homogeneity differences on the surfaces of both samples possibly dependent on unique decomposition behavior of $\mathrm{CaSO}_{4}$ and $\mathrm{BaSO}_{4}$ in the samples. Previous study indicated that thermal decomposition kinetics of metal sulphates (e.g. $\mathrm{MgSO}_{4}$ and $\mathrm{BaSO}_{4}$ ) vary significantly [35]. Fluxing effect of barium in production of ceramic and glass materials is also reported elsewhere [14,28]. (ii) At $1150^{\circ} \mathrm{C}$ and under the working conditions, the samples with $\mathrm{BaCO}_{3}$ additive saved their structural integrity, whereas the non-additive sample was bloated wholly because of the presence of $\mathrm{CaSO}_{4}$ in the as-received fly ash as will be explained later. Moreover, a partly melting or liquid phase formation on the sample surface started. Especially, the surface of the sintered sample with $10 \mathrm{wt} \% \mathrm{BaCO}_{3}$ additive had a very smooth and a glassy appearance. (iii) At $1100^{\circ} \mathrm{C}$, a significant difference on their structure was not seen, but only their color was getting darker with increasing the amount of additive.

\subsection{Phase analysis}

X-ray diffraction patterns of the Seyitömer fly ash (as-received) and all the sintered fly ash samples are given in Fig. 2. The Seyitömer fly ash consists of those phases: quartz $\left(\mathrm{SiO}_{2}\right)$, hematite $\left(\mathrm{Fe}_{2} \mathrm{O}_{3}\right)$, anorthite $\left(\mathrm{CaAl}_{2} \mathrm{Si}_{2} \mathrm{O}_{8}\right)$ and anhydrite $\left(\mathrm{CaSO}_{4}\right)$. This mineralogical composition is very similar to that in the paper [8] using the similar fly ash taken from the same power plant. But, it is not very similar to that in the [26], using the similar fly ash taken from the Seyitömer Power Plant, that is, mullite and enstatite minerals exist in the fly ash sample in that study, while they were not seen in our fly ash sample. After the sintering at $1100^{\circ} \mathrm{C}$, in the non-additive sample cristobalite which is a high temperature phase of quartz and spinel $\left[\mathrm{Mg},(\mathrm{Al}, \mathrm{Fe})_{2} \mathrm{O}_{4}\right]$ phases were occurred while the intensity of quartz peak was diminished. Moreover, cristobalite formation from quartz with increasing the temperature is encountered in the all sintered samples. Similar results on cristobalite formation have been obtained for different coal fly ashes $[21,25]$. With $\mathrm{BaCO}_{3}$ addition, peak intensities coming from anorthite and hematite increased and also witherite $\left(\mathrm{BaCO}_{3}\right)$ peaks were seen (Fig. 2). When considered the presence of witherite at $1100{ }^{\circ} \mathrm{C}$ this might be expressed that this temperature is insufficient to occur barite through ion exchange between $\mathrm{Ba}^{2+}$ in witherite and $\mathrm{Ca}^{2+}$ in anhydrite.

Even though the anhydrite phase is present in both the as-received and the non-additive samples sintered at $1100^{\circ} \mathrm{C}$, after their heat treatment at $1150{ }^{\circ} \mathrm{C}$ it was disappeared as seen in Fig. 2. This is due to the decomposition of anhydrite which leads to bloating of the non-additive sample. The bloating and also swelling of the sample sintered at $1150{ }^{\circ} \mathrm{C}$ results from the evolved gases such as $\mathrm{SO}_{2}, \mathrm{SO}_{3}$ and $\mathrm{O}_{2}$ during the thermal decomposition reaction of anhydrite. According to the literature [33] this reaction with two steps may be given as

$\mathrm{CaSO}_{4} \rightarrow \mathrm{CaO}+\mathrm{SO}_{3}$

$\mathrm{SO}_{3} \rightarrow \mathrm{SO}_{2}+1 / 2 \mathrm{O}_{2}$

A similar result on sintering of the Seyitömer fly ash fired at $1200{ }^{\circ} \mathrm{C}$ has been obtained by Yllmaz et al. [8] using original fly ash, while [21] reported such as bloating on the Yugoslavia fly ash fired $1190{ }^{\circ} \mathrm{C}$ due to the decomposition of metal sulfates. But, Yilmaz et al. [8] studied at 900,1000 , and $1200^{\circ} \mathrm{C}$, therefore, they were not able to see possible decomposition leading to swelling and bloating occurring at the temperature between 1100 and $1200{ }^{\circ} \mathrm{C}$. On the other hand, as $\mathrm{Fe}_{2} \mathrm{O}_{3}$ content of fly ash used by Ilic et al. [21] was relatively lower as compared to current study, therefore, the decomposition temperature of $\mathrm{CaSO}_{4}$ in the fly ash in [21] might be relatively higher than that of $\mathrm{CaSO}_{4}$ in the fly ash in this study. Because Merwe et al. [36] determined that $\mathrm{Fe}_{2} \mathrm{O}_{3}$ has a reducer effect on the decomposition temperature of anhydrite $\left(\mathrm{CaSO}_{4}\right)$ as in the case of alone. However, another study on Seyitömer fly ash fired at $1175^{\circ} \mathrm{C}$ does not mention thermal decomposition leading to swelling and bloating. In contrast it states that high density and low porosity sintered products were obtained [26]. It is likely that the absence of anhydrite in the fly ahs samples, contrary to the samples of current study, protected the negative effect of decomposition reactions. Essentially, as mentioned before pure anhydrite remains stable up to $1240{ }^{\circ} \mathrm{C}$ in an atmosphere of air, but in the presence of $25 \mathrm{wt} \% \mathrm{SiO}_{2}$ the temperature of thermal decomposition of anhydrite $\mathrm{CaSO}_{4}$ is lowered to about $1120^{\circ} \mathrm{C}$ [33]. However, $\mathrm{BaCO}_{3}$ addition caused a phase transformation from anhydrite $\left(\mathrm{CaSO}_{4}\right)$ to barite $\left(\mathrm{BaSO}_{4}\right)$ due to the exchange between Calcium and Barium in the sample during the sintering. Accordingly, $\mathrm{BaSO}_{4}$ peaks are seen in Fig. 2. In order to clearly see the reaction between $\mathrm{BaCO}_{3}$ and $\mathrm{CaSO}_{4}$, a mixture consisting of $\mathrm{BaCO}_{3}$ and $\mathrm{CaSO}_{4} \cdot 2 \mathrm{H}_{2} \mathrm{O}$ powders was prepared using $0.01 \mathrm{~mol}$ of each powder and sintered at $1150{ }^{\circ} \mathrm{C}$ at the same conditions given in the experiment section for fly ash samples, and subsequently its XRD analysis was conducted (Fig. 3). Almost all peaks in Fig. 3 belong to $\mathrm{BaCO}_{3}$ may be considered as a case for barite formation during the firing of the fly ash even though it does not represent the same conditions in the fly ash sample. As a result, it is assumed that $\mathrm{BaSO}_{4}$ shows a better stability against to thermal decomposition at $1150{ }^{\circ} \mathrm{C}$ than $\mathrm{CaSO}_{4}$ under the working conditions. Therefore, the bar shaped samples with $\mathrm{BaCO}_{3}$ additive saved their structural integrity at $1150^{\circ} \mathrm{C}$ (see Fig. 1) implying that bloating and swelling was inhibited by means of $\mathrm{BaCO}_{3}$ addition. In other words, the decomposition temperature of $\mathrm{CaSO}_{4}$ was shifted to a higher temperature above $1150{ }^{\circ} \mathrm{C}$.

After the sintering at $1200{ }^{\circ} \mathrm{C}$, the $\mathrm{BaSO}_{4}$ peaks are also disappeared because of the decomposition of $\mathrm{BaSO}_{4}$, whereas the peaks are seen at $1150{ }^{\circ} \mathrm{C}$ (Fig. 2). Indeed, it is reported that according to the XRD patterns the thermal stability of nearly pure $\mathrm{BaSO}_{4}$ is above $1200^{\circ} \mathrm{C}$ [37], which is sintered under the argon atmosphere, but in the presence of fly ash which includes fluxing metal oxides, i.e. $\mathrm{Na}_{2} \mathrm{O}, \mathrm{K}_{2} \mathrm{O}$ as well as complex mineralogical structure the thermal stability of barite might be decreased, e.g. anhydrite at $1150^{\circ} \mathrm{C}$. Consequently, both of the metal sulfates in the fly ash were decomposed at $1200^{\circ} \mathrm{C}$ which leads to totally bloating of the sintered samples (see Fig. 1). On the other hand, relatively higher peak intensities were obtained from anorthite and spinel phases in the sintered samples.

\subsection{SEM investigations}

The SEM micrographs taken from the fracture surface of the samples sintered at 1100 and $1150^{\circ} \mathrm{C}$ are given in Fig. 5a and b, respectively. In general, the samples were poorly sintered at $1100{ }^{\circ} \mathrm{C}$ comparing with the samples sintered at $1150^{\circ} \mathrm{C}$. This may be attributed to the heterogeneous packing of the fly ash powders. Likewise, Ilic et al. [21] reported poor sintering behavior of a fly ash without additive at $1130^{\circ} \mathrm{C}$. At $1100^{\circ} \mathrm{C}$, larger pores are seen in the samples containing $\mathrm{BaCO}_{3}$ when compared with nonadditive samples, however, pore amount and size distribution of both the samples with 5 and $10 \mathrm{wt} \% \mathrm{BaCO}_{3}$ were close to each other. According to physico-mechanical test results $\mathrm{BaCO}_{3}$ addition has an adversely effect on the fired fly ash at $1100{ }^{\circ} \mathrm{C}$. Since as known alkaline (i.e. $\mathrm{Na}, \mathrm{K}, \mathrm{Li}$ ) and alkaline earth (i.e. $\mathrm{Ca}, \mathrm{Mg}, \mathrm{Ba}$ ) ele- 

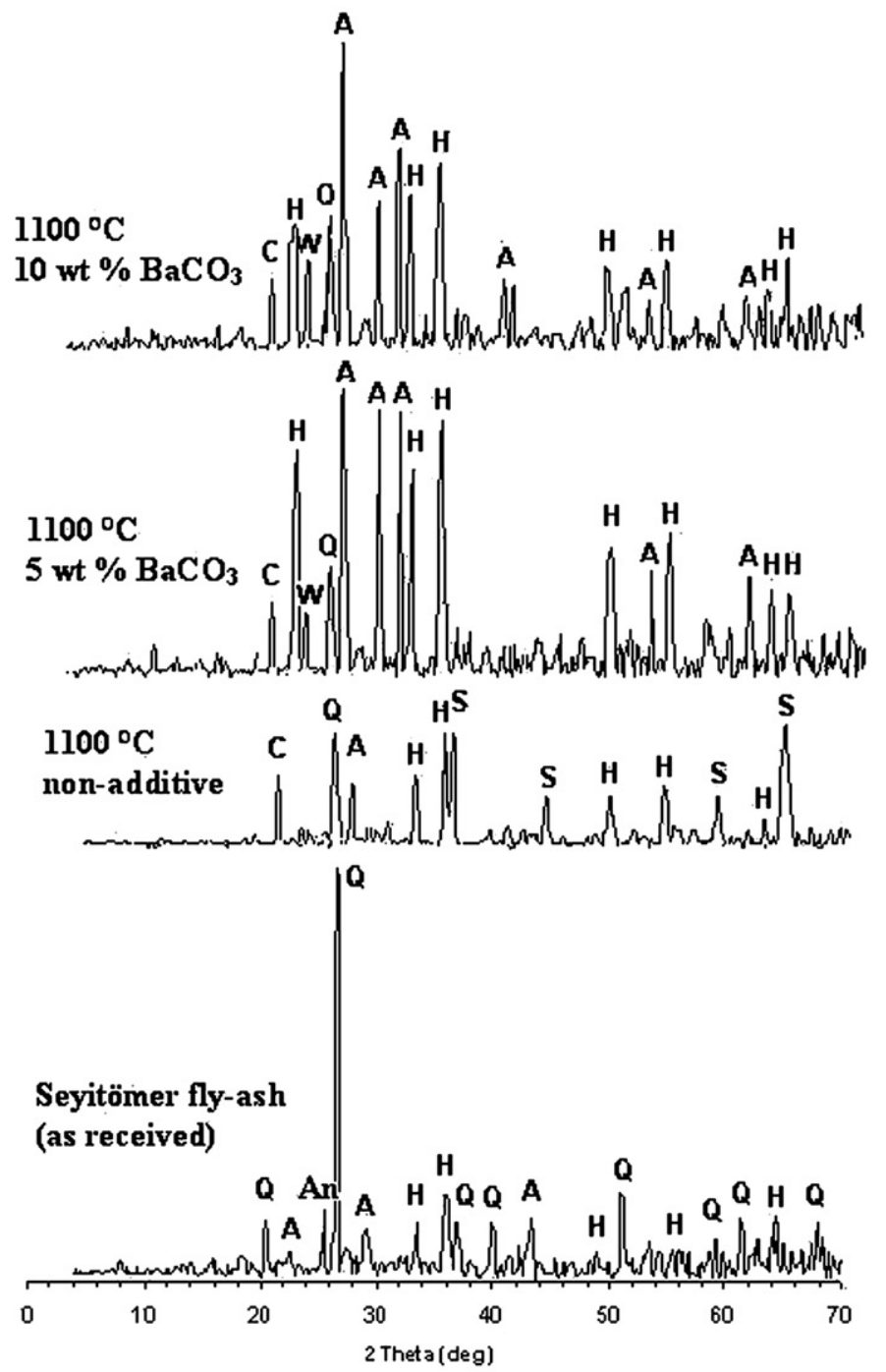

a
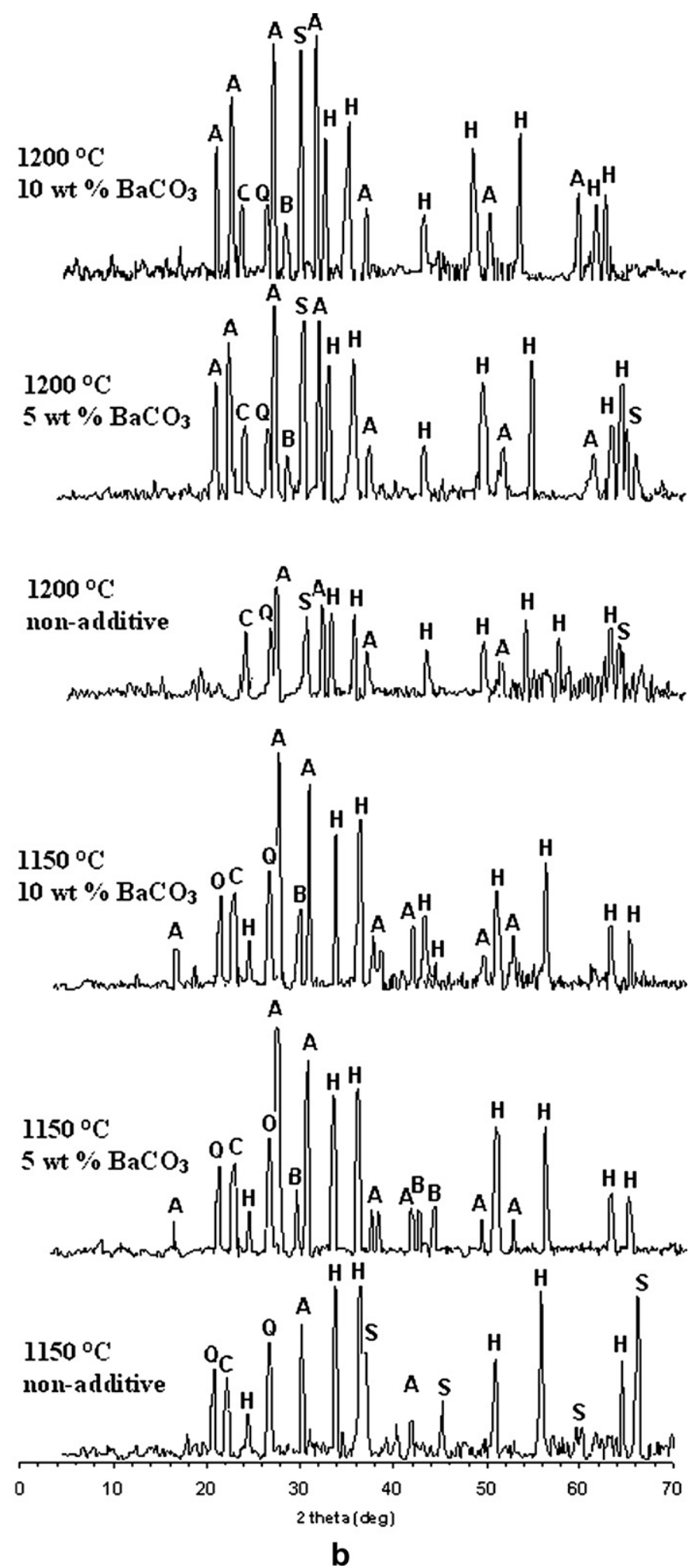

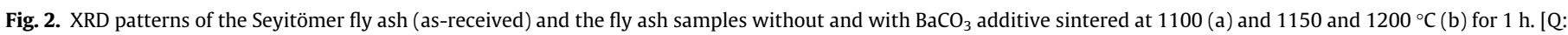
Quartz, H: Hematite, A: Anorthite, An: Anhydrite, C: Cristobalite, S: Spinel, W: Witherite, B: Barite.]

ments provide liquid phase in powder material during firing $[25,32]$. Normally, it is expected that $\mathrm{BaCO}_{3}$ as a fluxing agent leads to a better sintering of the fly ash. In order to explain this contrariness $\mathrm{Hg}$-porosimeter measurements were conducted. Indeed the obtained results from $\mathrm{Hg}$-porosimeter measurements performed on the two type samples fired at $1100^{\circ} \mathrm{C}$ without and $10 \mathrm{wt} \%$
$\mathrm{BaCO}_{3}$ additive fly ash supports this expectation, namely, the total pore areas are 4.34 and $3.29 \mathrm{~m}^{2} / \mathrm{g}$ and the average pore diameters are $\sim 0.05$ and $\sim 0.12 \mu \mathrm{m}$ for non-additive and $10 \mathrm{wt} \% \mathrm{BaCO}_{3}$ additive fly ash, respectively. With $\mathrm{BaCO}_{3}$ additive the total pore area decreases while the average pore diameter increases. This indicates that the small diameter of pores concentrated in large diameter 


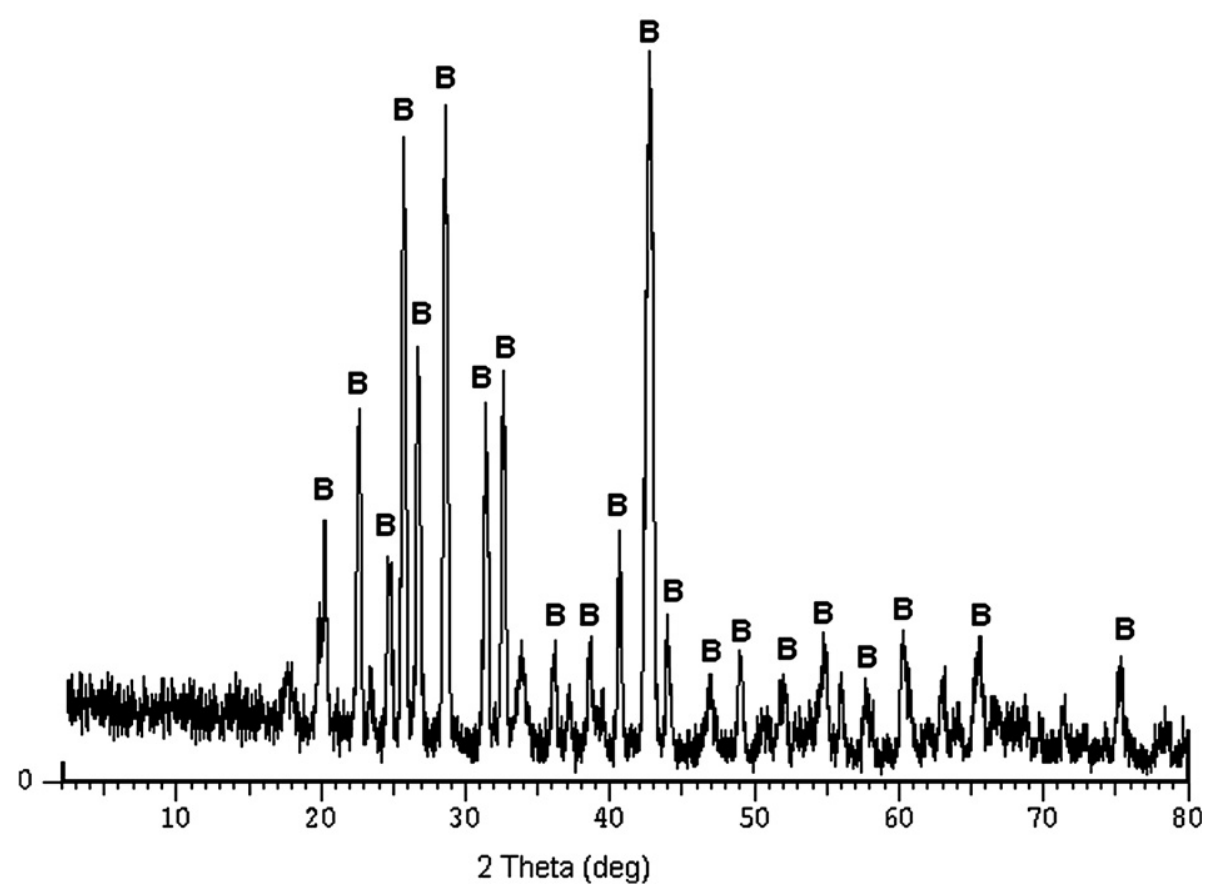

Fig. 3. XRD of the mixture $\left(0.01 \mathrm{~mol} \mathrm{BaCO}_{3}\right.$ and $0.01 \mathrm{~mol} \mathrm{CaSO} \mathrm{C}_{4} \cdot 2 \mathrm{H}_{2} \mathrm{O}$ powders) sintered at $1150{ }^{\circ} \mathrm{C}$ for $1 \mathrm{~h}$ in air (B: Barite).

pores during sintering to eliminate solid-vapor interfaces with higher energy and to occur solid-solid interfaces with lower energy [22,32]. Even though this case, physico-mechanical properties (Fig. 5) of $\mathrm{BaCO}_{3}$ additive fly ash samples were lower than that of non-additive. This contrariness could not be explained at present but it might be an investigation topic for a next study.

The structure of the non-additive samples sintered at $1150{ }^{\circ} \mathrm{C}$ was totally bloated and expanded owing to gas evolving during thermal decomposition of anhydrite as mentioned above. A similar bloating on a fly ash fired at $1190{ }^{\circ} \mathrm{C}$ is reported in the literature [21]. This difference possibly results from the chemical composition differences of the used fly ashes as explained before. The large pores (or voids) of about $500 \mu \mathrm{m}$ in diameter were occurred. The pores on the surface of non-additive sample are seen very clearly even by naked eye in Fig. 1. As known from the literature [22] some compounds become oxidized (or decomposed), generating gases as $\mathrm{SO}_{3}, \mathrm{CO}_{2}$, $\mathrm{CO}$ that are insoluble in the solid and the pressure of the gases can be sufficiently high to produce void in the solid. On the other hand, the sintering capability of the samples increased with $\mathrm{BaCO}_{3}$ addition and consequently the amount of (open or apparent) pore of the sample reduced as supported by Fig. 5b. This may results from the occurring of liquid phase and also promoting it with further increasing of $\mathrm{BaCO}_{3}$ having fluxing property. The best sintering capability of the sample was obtained by $10 \mathrm{wt} \%$ $\mathrm{BaCO}_{3}$ addition as seen from Fig. $4 \mathrm{~b}$, and this positive effect of $\mathrm{BaCO}_{3}$ on the sintering behavior was also supported by the physico-mechanical tests given in Fig. 5. In addition, in the SEM micrograph of $10 \mathrm{wt} \% \mathrm{BaCO}_{3}$ additive sintered at $1150{ }^{\circ} \mathrm{C}$ fly ash only some spherical isolated (closed) pores which indicates enhancement of the microstructural property (reduced porosity or water absorption, and increased bulk density and bending strength) with this ratio of the additive.

\subsection{Physico-mechanical tests}

In order to check the obtained results from the SEM and XRD analysis, some physico-mechanical tests were applied on the sintered samples. But those tests were not able apply on the samples sintered at $1200{ }^{\circ} \mathrm{C}$ due to their unsuitable forms as mentioned before (see Fig. 1). The variation of water absorption (wt\%) (Fig. 5a), apparent (or open) porosity (\%) (Fig. 5b), bulk density $\left(\mathrm{g} / \mathrm{cm}^{3}\right)$ (Fig. 5c) bending strength (MPa) (Fig. 5d) and linear shrinkage (\%) (Fig. 5e) of the samples sintered at 1100 and $1150{ }^{\circ} \mathrm{C}$ versus $\mathrm{BaCO}_{3}$ addition (wt\%) are given in Fig. 5. At $1100^{\circ} \mathrm{C}$, water absorption increases slightly with $\mathrm{BaCO}_{3}$ addition but the further addition did not importantly affect the sintering behavior of the fly ash. At $1150{ }^{\circ} \mathrm{C}$, water absorption suddenly decreases to $2 \%$ ratio at $5 \mathrm{wt} \% \mathrm{BaCO}_{3}$, and to zero at $10 \mathrm{wt} \% \mathrm{BaCO}_{3}$ additions (Fig. 5a). Fig. 5b shows that the apparent porosity (vol\%) of the sample sintered at $1100{ }^{\circ} \mathrm{C}$ increased gradually while that of the samples sintered at $1150{ }^{\circ} \mathrm{C}$ reduced sharply with $\mathrm{BaCO}_{3}$ addition. As explained before the sharp decrease at $1150^{\circ} \mathrm{C}$ may results from the inhibiting of the bloating and the swelling due to the $\mathrm{BaSO}_{4}$ formation, while the reason the small increase in the open porosity at $1100{ }^{\circ} \mathrm{C}$ is unclear. The further addition resulted no significant change on the porosity of the sample sintered at $1100{ }^{\circ} \mathrm{C}$ while that brings the porosity to zero after sintering at $1150^{\circ} \mathrm{C}$. The amount of water absorption is a natural result of the amount of apparent porosity $[32,38]$. So, the porosity curves have exactly the same trends with the water absorption curves which indicates that when the apparent porosity increases (or decreases) the water absorption also increases (or decreases). The maximum porosity (as $\sim 20 \%$ ) was obtained from the non-additive fly ash sample sintered at $1150{ }^{\circ} \mathrm{C}$ due to the wholly decomposition of anhydrite present in the sample and the minimum porosity (as $~ 0 \%$ ) was obtained by the sample with $10 \mathrm{wt} \% \mathrm{BaCO}_{3}$ additive sintered at $1150{ }^{\circ} \mathrm{C}$ because of the good sintering process as well as the phase transformation from anhydrite to barite. The porosity results for $1150{ }^{\circ} \mathrm{C}$ in Fig. $5 \mathrm{~b}$ are in accordance with the photographs (Fig. 1), the SEM micrographs (Fig. 4b) and the XRD patterns (Fig. 2).

$\mathrm{BaCO}_{3}$ addition significantly enhanced the bulk density at $1150^{\circ} \mathrm{C}$ whereas it causes to a little decrease in the bulk density at $1100^{\circ} \mathrm{C}$ (Fig. 5) agreeing with the results of apparent porosity and water absorption. As well known, bulk density is one of the most important properties of pressed powder since it directly influences bending strength, porosity, linear shrinkage and water 


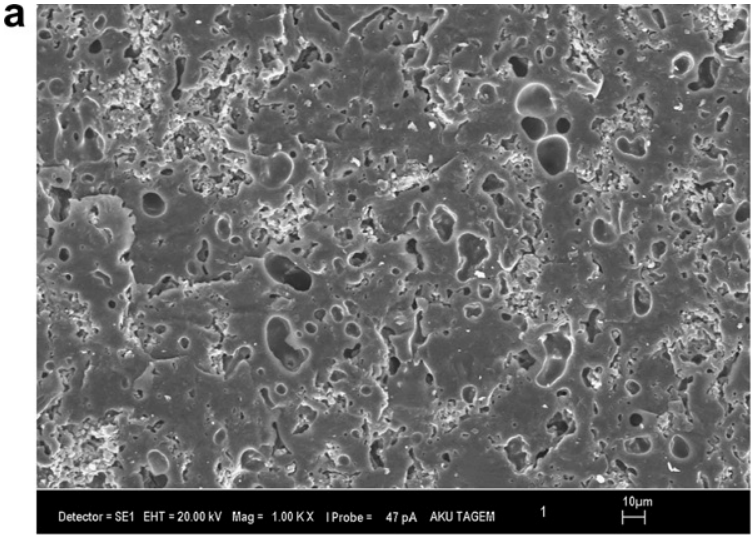

$1100{ }^{\circ} \mathrm{C}$, non-additive

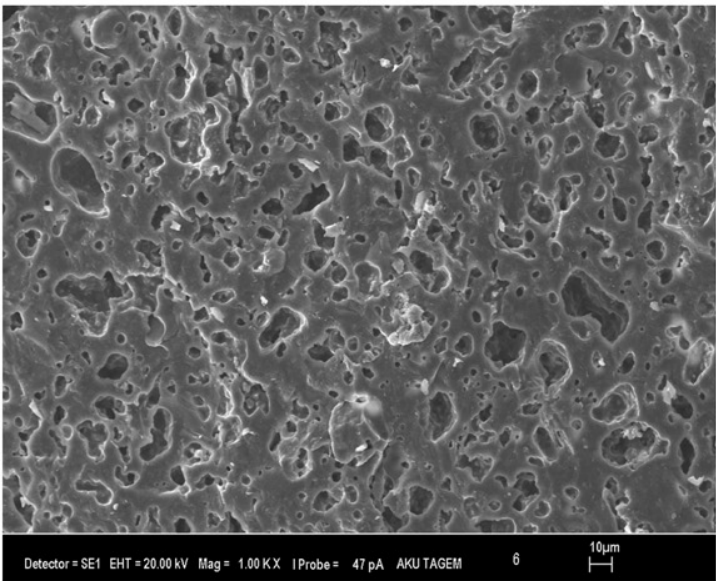

$1100{ }^{\circ} \mathrm{C}, 5 \mathrm{wt} \% \mathrm{BaCO}_{3}$

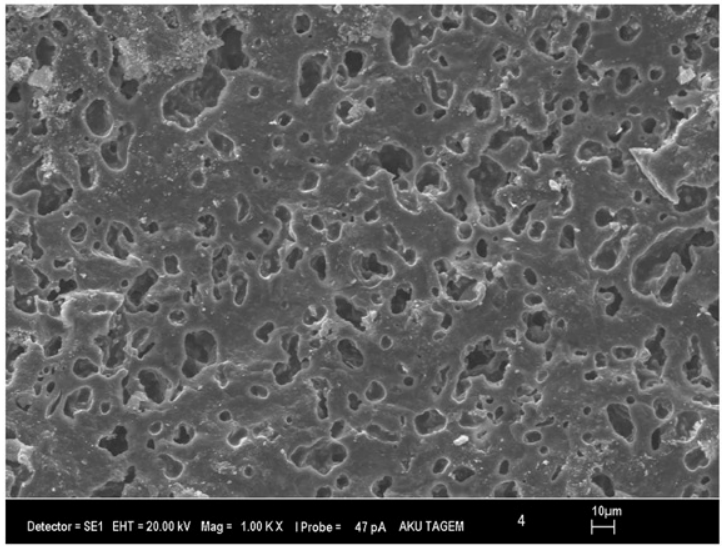

$1100{ }^{\circ} \mathrm{C}, 10$ wt $\% \mathrm{BaCO}_{3}$

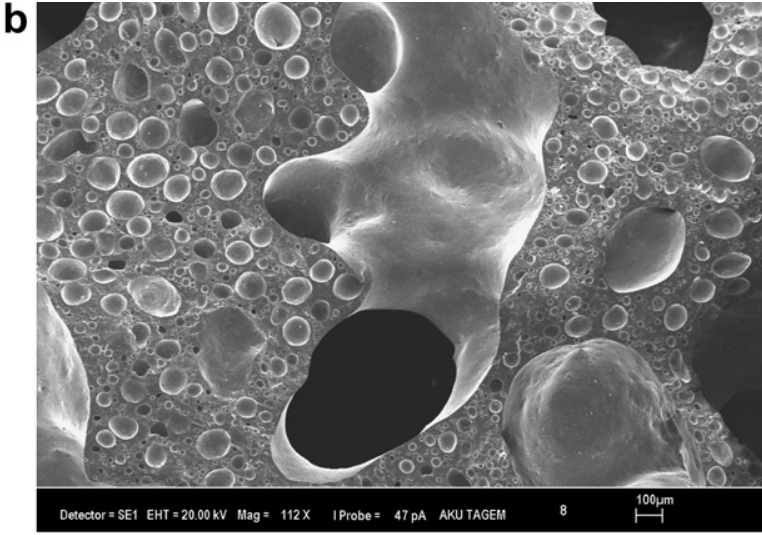

$1150{ }^{\circ} \mathrm{C}$, non-additive

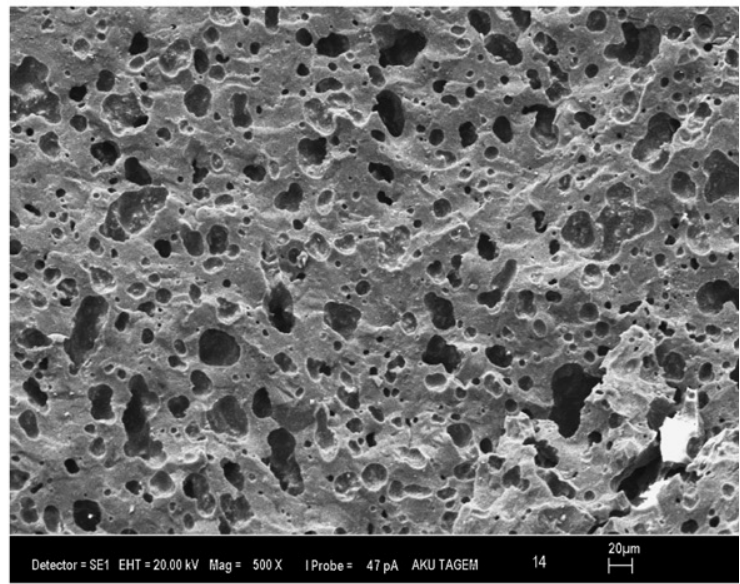

$1150{ }^{\circ} \mathrm{C}, 5$ wt $\% \mathrm{BaCO}_{3}$

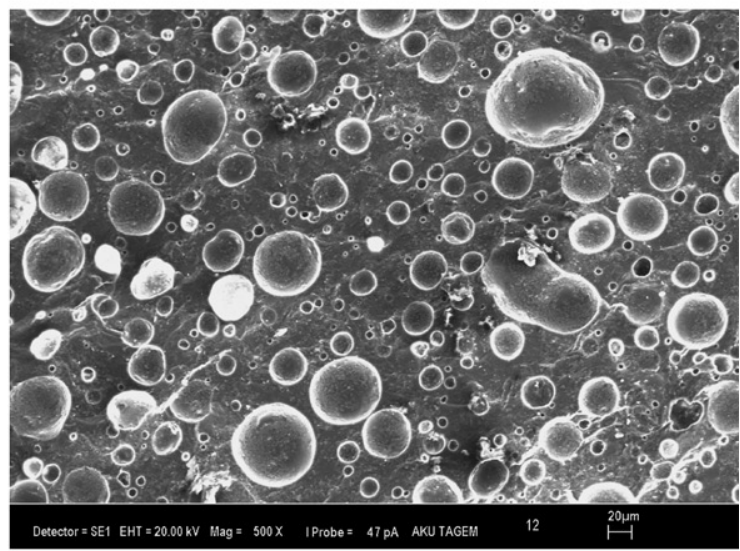

$1150{ }^{\circ} \mathrm{C}, 10$ wt $\% \mathrm{BaCO}_{3}$

Fig. 4. SEM micrographs of the fly ash samples without and with $\mathrm{BaCO}_{3}$ additive ( $5 \mathrm{wt} \%$ and $10 \mathrm{wt} \%$ ) sintered at (a) 1100 and (b) $1150{ }^{\circ} \mathrm{C}$ for $1 \mathrm{~h}$.

absorption [9,22]. The highest $\left(\sim 2.3 \mathrm{~g} / \mathrm{cm}^{3}\right)$ and the lowest $(\sim 1.2 \mathrm{~g} /$ $\mathrm{cm}^{3}$ ) density in the experiments were obtained at the sintering temperature of $1150{ }^{\circ} \mathrm{C}$ with the samples of $10 \mathrm{wt} \% \mathrm{BaCO}_{3}$ additive and the non-additive samples due to minimum and maximum apparent porosity, respectively. This highest density $\left(\sim 2.3 \mathrm{~g} / \mathrm{cm}^{3}\right)$ of $\mathrm{BaCO}_{3}$ additive fly ash, value obtained in this study is very close to the density $\left(2.43 \mathrm{~g} / \mathrm{cm}^{3}\right)$ obtained by Erol et al. [26] on the similar fly ash without additive sintered at $1175^{\circ} \mathrm{C}$ for $2 \mathrm{~h}$. It is interesting to obtain very close densities for the two studies although there are differences between the properties of used fly ashes.
However, it should be noted that in the study of [26] any decomposition process has not been encountered under the working conditions. On the other hand, Yilmaz et al. [8] obtained $\sim 1.7 \mathrm{~g} / \mathrm{cm}^{3}$ of bulk density at $1100^{\circ} \mathrm{C}$ for $1 \mathrm{~h}$ using the Seyitömer fly ash very similar to our fly ash samples, and this result is lower from the result $\sim 2.1 \mathrm{~g} / \mathrm{cm}^{3}$ obtained in this study. This may be attributed to the differences, during the sample preparation, i.e. the moistened ratio of granulated powders which can lead to difference compacting causing different final density [9]. In contrast to our result, Ilic et al. [21] studied at $1130,1150,1170$ and $1190{ }^{\circ} \mathrm{C}$ on the sintering 


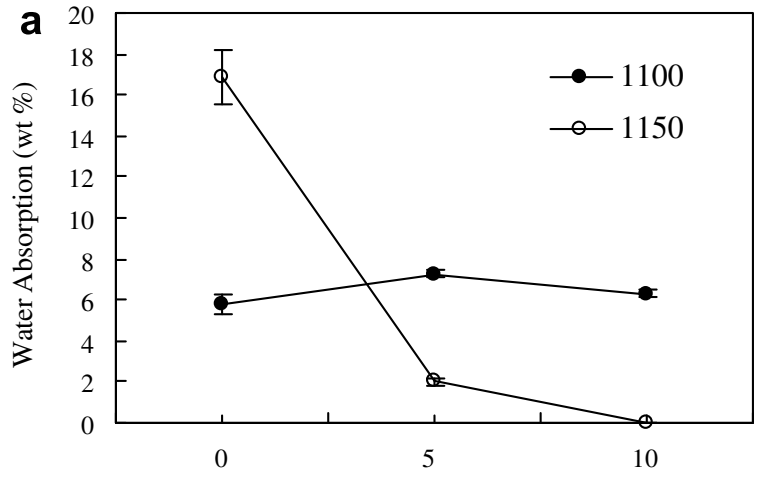

Amount of additive (wt \%)

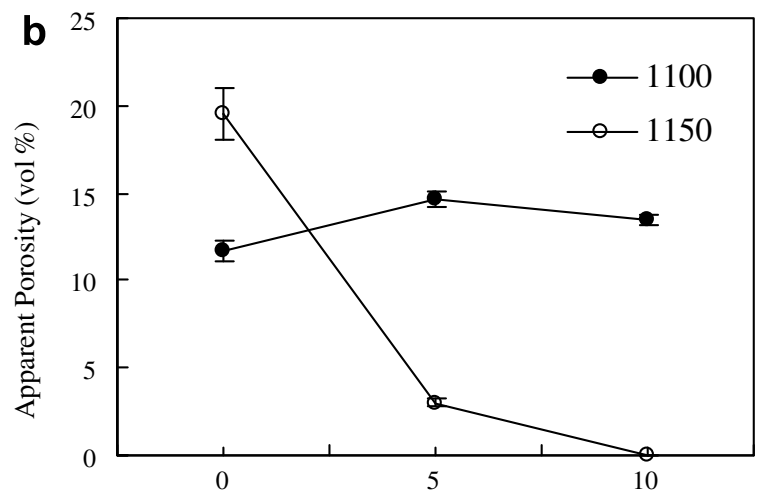

Amount of additive (wt \%)

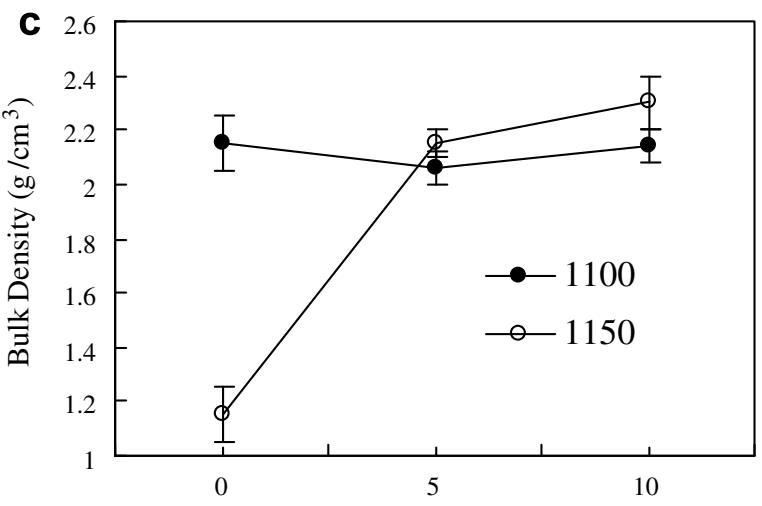

Amount of additive (wt \%)
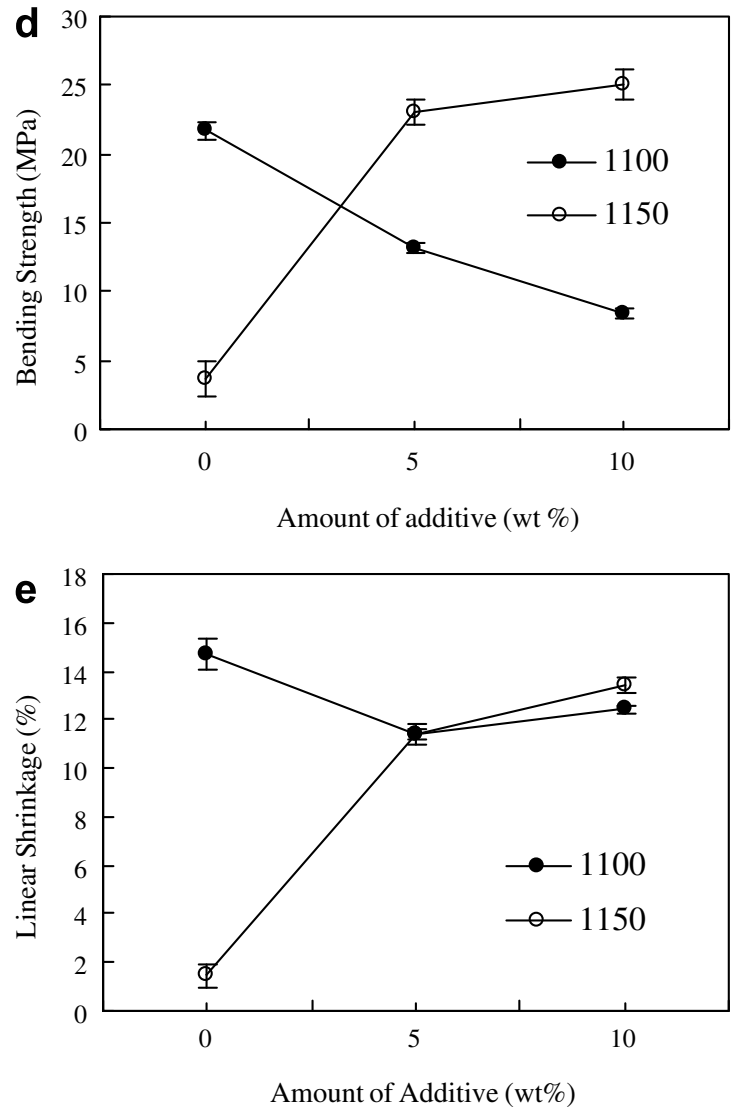

Amount of Additive (wt $\%$ )

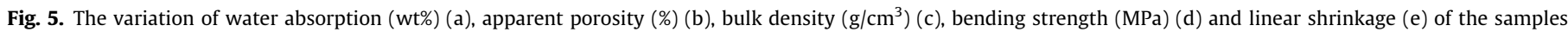
sintered at 1100 and $1150{ }^{\circ} \mathrm{C}$ versus $\mathrm{BaCO}_{3}$ addition (wt\%).

behavior of Yugoslavia fly ash without additive showed that the best result for density $\left(2.5 \mathrm{~g} / \mathrm{cm}^{3}\right)$ has been obtained at 1150 and $1170^{\circ} \mathrm{C}$ by the fly ash milled for $8 \mathrm{~h}$. This indicates that, as expected, particle size and particle size distribution of fly ashes as well as their chemical compositions has a significant effect on the physical and mechanical properties of fired fly ashes.

The variation of mechanical strength as bending strength of the sintered samples versus the amount of $\mathrm{BaCO}_{3}$ additive is given in Fig. $5 \mathrm{~d}$. The addition promotes the strength at $1150{ }^{\circ} \mathrm{C}$ while it leads to decrease in the strength at $1100{ }^{\circ} \mathrm{C}$ similar to the bulk density. The highest strength ( $\sim 25 \mathrm{MPa}$ ) was obtained with the sample of $10 \mathrm{wt} \% \mathrm{BaCO}_{3}$ additive sintered at $1150{ }^{\circ} \mathrm{C}$ accompanying a decrease in the porosity and increase in the bulk density. These results at $1150{ }^{\circ} \mathrm{C}$ were supported by SEM micrographs. According to the linear shrinkage curves of the fired samples, it decreases with $\mathrm{BaCO}_{3}$ addition at $1100{ }^{\circ} \mathrm{C}$, while it increase sharply with the additive at $1150{ }^{\circ} \mathrm{C}$. Shrinkage occurring similarly to the porosity decrease and to the density increase [32] could be supported by Fig. $5 \mathrm{~b}$. The porosity of the sample fired at $1100{ }^{\circ} \mathrm{C}$ increases with $\mathrm{BaCO}_{3}$ addition while linear shrinkage decreases. However, due to the swelling and bloating on the fired samples at $1150{ }^{\circ} \mathrm{C}$ as a result of decomposition of $\mathrm{CaSO}_{4}$ during firing, the linear shrinkage is at the minimum value. The samples reach to almost their original size before heat treatment. It is assumed that a part of $\mathrm{BaCO}_{3}$ added simultaneously react with $\mathrm{CaSO}_{4}$ to form $\mathrm{BaSO}_{4}$ while the other part contribute to liquid phase which enhances sintering process. Benavidez et al. [24] also reported that the densification of the fly ash without additive sintered above $1180^{\circ} \mathrm{C}$ is controlled by the presence of liquid phase. Accordingly, the $\mathrm{BaCO}_{3}$ addition either inhibits the bloating or causes to densification accompanying with increase in shrinkage as clearly seen from Fig. $5 c$ and e. Maximum shrinkage occurs at $10 \mathrm{wt} \% \mathrm{BaCO}_{3}$ addition level in 
which the apparent porosity is nearly zero. The physico-mechanical properties of the Seyitömer fly ash with 5 and $10 \mathrm{wt} \% \mathrm{BaCO}_{3}$ additive sintered at $1150{ }^{\circ} \mathrm{C}$ are in acceptable level to produce a fired building materials such as tile according to Turkish Standards adapted to European Norms (TSEN 14411) [39].

\section{Conclusions}

The results of this study can be summarized as the following:

- The Seyitömer fly ash without additive was bloated completely when sintered at $1150{ }^{\circ} \mathrm{C}$ due to the thermal decomposition of anhydrite. $\mathrm{BaCO}_{3}$ additions at levels of 5 and $10 \mathrm{wt} \%$ into the fly ash, inhibited the bloating and the swelling as a result of phase transformation from anhydrite $\left(\mathrm{CaSO}_{4}\right)$ to barite $\left(\mathrm{BaSO}_{4}\right)$ during sintering as supported by XRD analysis and photographs.

- $\mathrm{BaCO}_{3}$ addition had a significant positive effect on the sintering of the fly ash at $1150{ }^{\circ} \mathrm{C}$, whereas it indicated a negative effect on the sintering at $1100^{\circ} \mathrm{C}$.

- The all fly ashes without and with $\mathrm{BaCO}_{3}$ addition sintered at $1200^{\circ} \mathrm{C}$ are totally bloated due to decomposition of metal sulfates $\left(\mathrm{CaSO}_{4}\right.$ and $\left.\mathrm{BaSO}_{4}\right)$, and melted at this temperature. The further increase in $\mathrm{BaCO}_{3}$ level leads to a more melting because of its fluxing effect.

- Both bloating and swelling problems of the fired ceramic products made from the $100 \%$ fly ashes including anhydrite, fired at about $1150{ }^{\circ} \mathrm{C}$, may be solved by $\mathrm{BaCO}_{3}$ addition. Moreover, the reasonable physico-mechanical properties have been obtained from the sample containing $10 \mathrm{wt} \% \mathrm{BaCO}_{3}$ and sintered at $1150^{\circ} \mathrm{C}$ suggesting the Seyitömer fly ash with the aid of $\mathrm{BaCO}_{3}$ could be utilized as a possible raw material to produce fired ceramic materials.

\section{References}

[1] Tütünlü F, Atalay Ü, Utilization of fly ash in manufacturing of building bricks. In: International ash utilization symposium, Utah - USA; 2001. <http:// whocares.caer.uky.edu/wasp/AshSymposium/AshLibraryAgenda.asp>.

[2] Özdemir O, Çelik MS. Characterization and recovery of lignitic fly ash by products from the Tunçbilek power station. Can Metall Quart 2002;41(2): 143-50.

[3] Özdemir O, Ersoy B, Celik MS. Separation of pozzolonic material from lignitic fly ash of Tunçbilek power station. In: International ash utilization symposium, Utah - USA; 2001. <http://www.flyash.info/2001/benef1/45ozdem.pdf>.

[4] Iyer RS, Scott JA. Power station fly ash - a review of value-added utilization outside of the construction industry. Resour Conserv Recycl 2001;31:217-28.

[5] Sebök T, Simonik J, Kulisek K. The compressive strength of samples containing fly ash with high content of calcium sulfate and calcium oxide. Cem Concr Res 2001;31:1101-7.

[6] Kula İ, Olgun A, Erdoğan Y, Sevinç V. Effects of colemanite waste, coal bottom ash, and fly ash on the properties of cement. Cem Concr Res 2001;31:491-4.

[7] Alonso JL, Wesche K. Characterization of fly ash, In: Wesche K, editor. Fly ash in concrete (properties and performance), E\&FN Spon/Chapman and Hall; 1991.

[8] Yılmaz S, Sen S, Günay V, Özkan OT. Utilisation of power fly-ash as a building material. Tile Brick Int 1997;3(4):297-300.

[9] Pirmaksa K, Wilhelm M, Wruss W. A new approach to the production of bricks made of $100 \%$ fly ash. Tile Brick Int 2000;16(6):428-31.
[10] Kayali O. High performance bricks from fly ash. In: International ash utilization symposium; 2005. <http://www.flyash.info/2005/1kay.pdf>.

[11] Erol M, Genç A, Öveçoğlu ML, Yücelen E, Küçükbayrak S, Taptık Y. Characterization of a glass-ceramic produced from thermal power plant fly ashes. J Eur Ceram Soc 2000;20:2209-14.

[12] Sheng J, Huang BX, Zhang J, Zhang H, Sheng J, Yu S, Zhang M. Production of glass from coal fly ash. Fuel 2003;82:181-5.

[13] Sheng J. Vitrification of borate waste from nuclear power plant using coal fly ash. (I) Glass formulation development. Fuel 2001;80:1365-9.

[14] Peng F, Liang K, Hu A, Shao H. Nano-crystal glass-ceramics obtained by crystallization of vitrified coal fly ash. Fuel 2004;83:1973-7.

[15] Erol M, Küçükbayrak S, Ersoy-Meriçboyu A. Characterization of coal fly ash for possible utilization in glass production. Fuel 2007;86:706-14.

[16] Kumar S. Fly ash-lime-phosphogypsum hollow blocks for walls and partitions. Build Environ 2003;38:291-5.

[17] Ikeda K, Tomisaka T. Physical properties of FGL, novel porous materials prepared from fly ash, gypsum and lime with special emphasis to the thermal conductivity. In: Proceedings Silicer'90 silicate ceramics. Nürnberg: Ceramic Forum International; 1990. p. 84-91.

[18] Mukherji SK, Machhoya BB, Savsani RM, Vyas DR, Dan TK. The utilization of fly ash in the preparation of ceramic tableware and artware. British Ceram Trans 1993;92(6):254-7.

[19] Hwang JY, Huang X, Hein AM. Synthesizing mullite from beneficiated fly ash. JOM 1994:36-9. May.

[20] Yıldırım MS, Yaşar B, Cengiz Y. Utilization of fly ash polypropylene waste in the production of a new porous composite material. J Porous Mater 1996;3:189-91.

[21] Ilic M, Cheeseman C, Sollars C, Knight J. Mineralogy and microstructure of sintered lignite coal fly ash. Fuel 2003;82:331-6.

[22] Rahaman MN. Ceramic Processing and Sintering. New York: Marcel Dekker Inc.; 1995.

[23] Bayat O. Characterization of Turkish fly ashes. Fuel 1998;77(9/10):1059-66.

[24] Benavidez E, Graselli C, Quaranta N. Densification of ashes from a thermal power plant. Ceram Int 2003;29:61-8.

[25] Mollah MYA, Promreuk S, Schennach R, Cocke DL, Güler R. Crystobalite formation from thermal treatment of Texas lignite fly ash. Fuel 1999;78:1277-82.

[26] Erol M, Küçükbayrak S, Ersoy-Meriçboyu A. Characterization of sintered coal fly ashes. Fuel 2007. doi:10.1016/j.fuel.2007.07.002 (in Press)

[27] Satapathy LN. The physical, thermal and phase identification studies of zirconia-flyash material. Ceram Int 1998;24:199-203.

[28] Toydemir N. Ceramic building materials. ITU-Publishing Center; 1991 [in Turkish].

[29] Patnaik P. Handbook of inorganic chemicals. New York: Mc-Graw Hill; 2002.

[30] Katyal NK, Ahluwalia SC, Parkash R. Effect of barium on the formation of tricalcium silicate CEM. Concr Res 1999;29:1857-62.

[31] Dei L, Mauro M, Bitossi G. Characterization of salt efflorescence in cultural heritage conservation by thermal analysis. Thermochim Acta 1998;317: 133-40.

[32] Kingery WD. Introduction to ceramics. New York: John Wiley and Sons Inc.; 1960.

[33] Ingo GM, Chiozzini G, Faccenda V, Bemporad E, Riccucci C. Thermal and microchemical characterizations of $\mathrm{CaSO}_{4}-\mathrm{SiO}_{2}$ investment materials for casting jewellery alloys. Thermochim Acta 1998;321:175-83.

[34] ASTM C 618 (American society for testing and materials). Fly ash and raw or calcined natural pozzolan for use as, mineral admixture in portland cement concrete, Philadelphia, PA ASTM; 1997.

[35] L'vov BV, Ugolkov VL. Kinetics of free-surface decomposition of magnesium and barium sulfates analyzed thermogravimetrically by the third law method. Thermochim Acta 2004;411:73-9.

[36] Merwe EM, Strydom CA, Potgieter JH. Thermogravimetric analysis of the reaction between carbon and $\mathrm{CaSO}_{4} \cdot 2 \mathrm{H}_{2} \mathrm{O}$, gypsum and phosphogypsum in an inert atmosphere. Thermochim Acta 1999;340-341:431-7.

[37] Torres J, Mendez J, Sukiennik M. Transformation enthalpy of the alkali-earths sulfates $\left(\mathrm{SrSO}_{4}, \mathrm{CaSO}_{4}, \mathrm{MgSO}_{4}, \mathrm{BaSO}_{4}\right)$. Thermochim Acta 1999;334:57-66.

[38] Hernandez-Crespo MS, Rincon JMa. New porcelainized stoneware materials obtained by recycling of MSW incinerator fly ashes and granite sawing residues. Ceram Int 2001;27:713-20.

[39] TS EN 14411, Ceramic tiles-definitions, classification, characteristics and marking, March 09; 2006. 